\title{
HUMIC ACID AND Azospirillum brasilense APPLIED TO COTTON SEEDS
}

Sebastião Ferreira de Lima ${ }^{1}$, Cátia Aparecida Simon ${ }^{2}$, Rafael da Costa Leite ${ }^{1}$, Kenio Batista Nogueira ${ }^{1}$; Rita de Cássia Félix Alvarez ${ }^{1}$

${ }^{1}$ Universidade Federal de Mato Grosso do Sul, Campus Chapadão do Sul E-mail: sebastiao.lima@ufms.br; rafaeldacostaleite@hotmail.com; kenio.nogueira@ufms.br; rita.alvarez@ufms.br

${ }^{2}$ Universidade de São Paulo, Escola Superior de Agricultura “Luiz de Queiroz”. E-mail: catiasimonsimon@gmail.com

\begin{abstract}
This work aimed at evaluating the effect of the application of humic acid and Azospirillum brasilense on cotton seeds. Only the variables germination percentage and abnormal seedlings were not influenced by the treatments. The use of humic acid or A. brasilense alone favors the physiological characteristics of cotton seeds. There was increase of the parameters of root and total dry matter, with the doses of A. brasilense only in the absence of humic acid.
\end{abstract}

Keywords: Azospirillum brasilense, bioregulators, Gossypium hirsutum, Humykos ${ }^{\circledR}$

\section{ÁCIDO HUMICO E Azospirillum brasilense APLICADO ÀS SEMENTES DE ALGODÃO}

\section{RESUMO}

Este trabalho teve como objetivo avaliar o efeito da aplicação de ácido húmico e Azospirillum brasilense em sementes de algodão. Somente as variáveis porcentagem de germinação e mudas anormais não foram influenciadas pelos tratamentos. O uso de ácido húmico ou A. brasilense sozinho favorece as características fisiológicas das sementes de algodão. Maiores doses de bactérias favorecem ESI e germinação. Houve aumento para os parâmetros de raiz e matéria seca total, com as doses de $A$. brasilense apenas na ausência de ácido húmico.

Palavras-chave: Azospirillum brasilense, biorreguladores, Gossypium hirsutum, Humykos ${ }^{\circledR}$ 


\section{INTRODUCTION}

Metabolic and morphogenetic processes promote the development of the embryo in plants that are primarily controlled by environmental and endogenous factors. At the germination stage, the seed must undergo three procedures: imbibition, organelles reactivation and seeds reserve breakage. The hydration of bicoloid substances and the rearrangement of cellular structures occur at the imbibition stage due to semipermeability of the cell membrane, allowing organic molecules and water to enter into the cells by diffusion (CASTRO et al., 2004), which facilitates the application of different treatments to the seeds.

Cotton crops stand out in the Brazilian agriculture, reaching about one million hectares cultivated per year, with high production cost (CONAB, 2016). This fact leads to the demand of inputs to reduce costs. The current technological level applied to cotton crops allows the insertion of new products to improve fiber yield. Azospirillum. brasilense, for instance, when inoculated with seeds, promotes plant growth owing to the excretion of part of the nitrogen fixed by this bacterium, which is directly captured by the associated plant. The bacterium also favors the mineralization process and thus contributes to the additional nitrogen input to the plants. However, inoculation of associative bacteria with non-leguminous species, even when the plant can fix nitrogen, does not supply the total nitrogen required (HUNGRIA, 2011).

The quantity of diazotrophic bacteria can be increased by humic acids, which are final products of the decomposition of organic residues, representing the main component of organic matter in water, soils, and sediments. This increase may boost the beneficial effects on the host plant (CANELLAS et al., 2008; MARQUES JÚNIOR et al., 2008; CONCEIÇÃO et al., 2009), allowing positive results in relation to plant development. Rodrigues et al. (2014) observed an increase in leaf dry matter in wheat crops cultivated with humic acid associated with diazotrophic bacteria (strain Ab-V5).

The association of humic acid with endophytic diazotrophic bacteria of the genus Herbaspirillum increased roots dry matter in sugar cane micro seed pieces, without thermotherapy; however, no statistical difference was observed (MARQUES JUNIOR et al., 2008). The same authors reported that the use of humic acid, regardless of thermotherapy and without the association with diazotrophic bacteria, was the primary plant growth agent in sugar cane, promoting shoot and root growth. Humic acid can also be used in fruit species to increase yield. For instance, Ferrara \& Brunetti (2010) verified that humic acid increased the number of berries of cultivar Italia at full bloom. 
Studies on A. brasilense have focused on grass species. Thus, few studies have reported the use of this bacterium in cotton seeds. Considering the importance of this crop, and since it is not a grass species, this work seeks to test the hypothesis that the inoculation of bacteria of the genus Azospirillum with humic acid can improve physiological characteristics of cotton seeds. Therefore, the objective of this work was to evaluate the effect of inoculation of $A$. brasilense associated with humic acid on cotton seeds.

\section{MATERIAL AND METHODS}

The experiment was carried out at the Seed Technology Laboratory of the Federal University of Mato Grosso do Sul - UFMS, Campus Chapadão do Sul, State of Mato Grosso do Sul, Brazil, from June to July 2013. Cotton seeds of the cultivar FMT 701 were treated with abamectin (Avicta ${ }^{\circledR} 500$ FS) 0.3 L

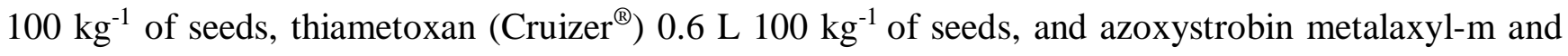

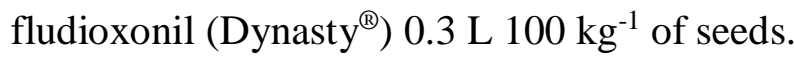

The experiment was carried out in a completely randomized design, in a 2 x 6 factorial scheme. The treatments consisted of presence and absence of humic acid (Humykos ${ }^{\circledR}$, composed of $18 \%$ humic acid, $3 \%$ fulvic acid, $98 \%$ soluble humate, $12 \%$ organic carbon, $60 \%$ CTA) at the dose of $3 \mathrm{~mL} \mathrm{~kg}^{-1}$ of seeds and $A$. brasilense (Masterfix ${ }^{\circledR}$ Gramíneas) at six doses $(0 ; 50.0 ; 100.0 ; 150.0 ; 200.0$ and 250; 0 mL $\mathrm{kg}^{-1}$ of seeds). The inoculant and the humic acid were applied directly to the seeds in plastic bags using a volumetric pipette. Afterward, the plastic bags were closed and shaken for treatments homogeneity.

For the germination test, 400 seeds were used in four replications of 100 seeds, in a germitest paper roll moistened with distilled water, in the proportion of 2.5 times its non-hydrated mass, and stored in a germination chamber at $25 \pm 1{ }^{\circ} \mathrm{C}$. The seedlings were evaluated at four and twelve days after sowing (BRASIL, 2009).

Emergence speed index (ESI) and the percentage of seedling emergence (PSE) were evaluated using 200 seeds per treatment, with four replications of 50 seeds. Sowing was carried out in expanded polystyrene-multicellular trays $(622 \times 320 \times 75 \mathrm{~mm})$ containing sand, moistened according to its field capacity (60\%). After sowing, the seeds were covered with a layer of sand, and then the trays were stored in a greenhouse at room temperature.

For the ESI, the number of emerged seedlings was counted daily from the 5th day, which refers to the first emerged seedling. This parameter is calculated by the sum of the number of normal emerged plants $(\mathrm{G} 1, \mathrm{G} 2, \mathrm{G} 3, \ldots, \mathrm{Gn})$ divided by the number of days $(\mathrm{N} 1, \mathrm{~N} 2, \mathrm{~N} 3, \ldots, \mathrm{Nn})$ between sowing and 
emergence (10 days), according to the formula described by Maguire (1962). Emerged seedlings were directly counted to determine the percentage of seedling emergence (PSE) at five days after sowing. Abnormal seedlings (AS), which correspond to the plants with root system smaller than $2 \mathrm{~mm}$ in length and with erect and well-developed coleoptile, were recorded, as well as the percentage of germination (PG).

Twenty seeds per replication were used to determine seedling growth, with four replications per treatment. Seeds were placed on two sheets of germitest paper, and covered with another sheet of the same paper; the sheets were moistened with distilled water. At eight days after sowing, shoot length (SL), root length (RL), and total length (TL) were evaluated. Afterward, shoots and roots of the seedlings were placed in paper bags, separately, and dried in a forced-air-circulation oven at a temperature of $65^{\circ} \mathrm{C}$ for $24 \mathrm{~h}$. Subsequently, the seedlings were weighed to determine root dry matter (RDM), shoot dry matter (SDM), and total dry matter (TDM).

Data were subjected to analysis of variance, and the means obtained in function of the doses of A. brasilense were subjected to regression analysis. The other data were compared by the Tukey's test at $5 \%$ probability.

\section{RESULTS AND DISCUSSION}

The variables ESI, PG, PSE, and AS presented no significant interaction for humic acid and doses of Masterfix ${ }^{\circledR}$. Humic acid influenced PSE only, whereas A. brasilense influenced ESI and PSE (Table 1). Piccolo (2001) reports that humic acid may influence seedlings development when applied in solution; however, in this study, it influenced only PSE.

The addition of $A$. brasilense at a dose of up to $109 \mathrm{~mL} \mathrm{~kg}^{-1}$ of seeds reduced ESI values, which reached 7.60, resuming growth from that point until the maximum dose, when ESI reached 8.4 (Figure 1A). The result obtained is contradictory to that described by Souza et al. (2014), who reported that inoculation with $A$. brasilense over time $(0,24,48$ and $72 \mathrm{~h})$ and inoculation by dilution in water $(0,1,2$, and $3 \mathrm{~mL} \mathrm{~mL}^{-1}$ ) presented no statistical difference for ESI in sweet corn seeds. However, Rampim et al. (2014) confirmed that microbiolization with A. brazilense and Bradyrhizobium elkanii increased ESI in the development of canafistula, which is in agreement with this work. This result may be related to the fact that diazotrophic bacteria stimulated the production of growth regulating hormones, such as cytokinin, auxin, and gibberellin, consequently promoting cell expansion and division (HUNGRIA, 2011). 
Table 1. Summary of analysis of variance for the variables ESI, PG, AS, and PSE of cotton seedlings in response to treatments with A. brasilense and humic acid. Chapadão do Sul, 2013.

\begin{tabular}{llllll}
\hline Source of variation & DF & ESI & PG & PSE & AS \\
\hline Humic acid (HA) & 1 & $0.34^{\text {ns }}$ & $0.01^{\text {ns }}$ & $325.65^{* *}$ & $21.55^{\text {ns }}$ \\
Masterfix $^{\circledR}(M)$ & 5 & $0.99^{*}$ & $20.56^{\text {ns }}$ & $86.30^{* *}$ & $16.69^{\text {ns }}$ \\
HA x M $^{\circledR}$ & 5 & $0.59^{\text {ns }}$ & $31.71^{\text {ns }}$ & $44.58^{\text {ns }}$ & $8.93^{\text {ns }}$ \\
Error & 36 & 0.36 & 32.69 & 29.12 & 26.91 \\
\hline CV $(\%)$ & & 7.64 & 9.29 & 7.97 & 26.36 \\
Mean & & 7.89 & 61.53 & 67.68 & 19.67 \\
\hline
\end{tabular}

* Significant at 5\%,** Significant at $1 \%$ probability. ${ }^{\text {ns }}$ Not significant.
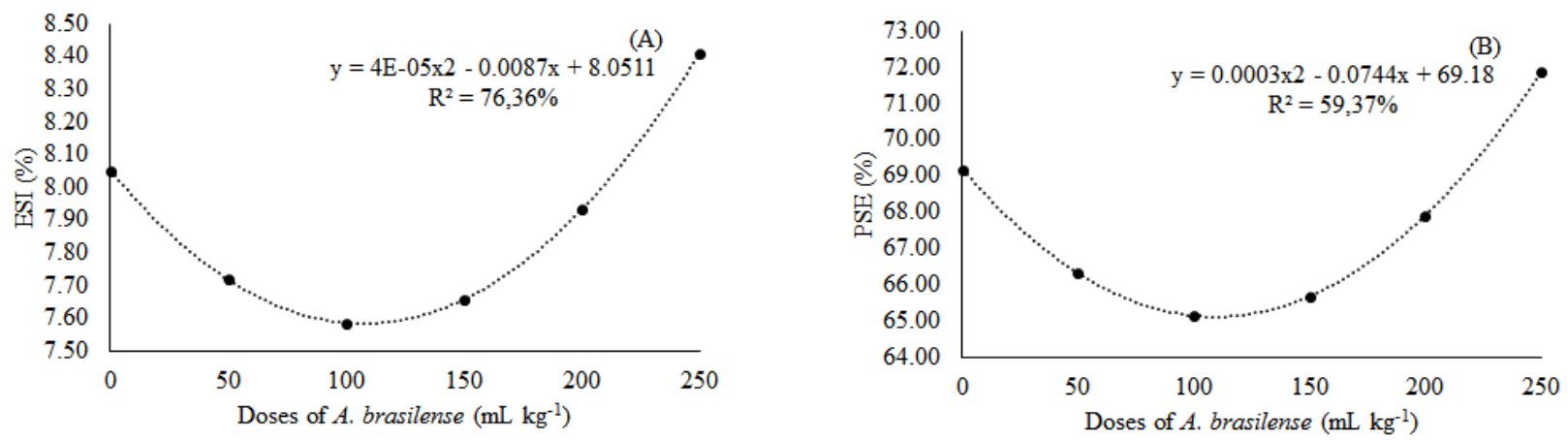

Figure 1. Effect of the doses of $A$. brasilense and humic acid on cotton seedlings. Where: (A) emergence speed index - ESI (\%); and, (B) percentage of seedlings emergence - PSE (\%). Chapadão do Sul, 2013.

PSE had the same behavior as ESI, i.e., it reduced until the dose of $124 \mathrm{~mL} \mathrm{~kg}^{-1}$, reaching $64.6 \%$, and then resuming growth until the highest dose of $A$. brasilense, when it reached $71.8 \%$ (Figure 1B). The use of humic acid promoted greater cotton seedlings emergence (Table 2). This fact is due to the ability of humic acid to increase nutrient accumulation and plant biomass (BALDOTTO et al., 2014). These results corroborate with those of Matysiak et al. (2011), who observed an increase in the percentage of germination of corn seeds immersed in humic acid for $24 \mathrm{~h}$ when compared with the control.

SL was singly affected by humic acid and $A$. brasilense, while the variables RL, TL, SDM, RDM, and TDM were influenced by the interaction between these two factors (Table 3).

The use of humic acid provided longer shoot length when compared with the control (Table 4). Likewise, Bernardes et al. (2011) verified that the presence of humic acid in tomato plants increased seedlings height. According to Rocha \& Rosa (2003), the use of humic acid may interfere with plant 
metabolism, leading to effects such as metal complexation, increased cation exchange capacity, increased nutrient supply, and increased moisture retention, which are promising characteristics.

Table 2. Percentage of seedling emergence (PSE) using humic acid. Chapadão do Sul, 2013.

\begin{tabular}{cc}
\hline Products & PSE \\
\hline With humic acid & $65.07 \mathrm{~b}$ \\
Without humic acid & $70.28 \mathrm{a}$ \\
\hline
\end{tabular}

*Values followed by the same letter in the column did not differ from each other $(\mathrm{p}<0.05)$ by the Tukey's test.

Table 3. Summary of the analysis of variance for the cotton seedlings variables SL, RL, TL, SDM, RDM, and TDM in response to treatments with A. brasilense and humic acid. Chapadão do Sul. 2013.

\begin{tabular}{llllllll}
\hline \multirow{2}{*}{ Source of variation } & DF & \multicolumn{4}{c}{ Mean squares } \\
\cline { 2 - 7 } & & SL & RL & TL & SDM & RDM & TDM \\
\hline Humic acid $(\mathrm{AH})$ & 1 & $4.15^{* *}$ & $5.44^{* *}$ & $19.11^{* *}$ & $0.00^{\text {ns }}$ & $0.00^{\text {ns }}$ & $0.00^{\text {ns }}$ \\
Masterfix $^{\circledR}(\mathrm{M})$ & 5 & $0.69^{* *}$ & $5.62^{* *}$ & $10.06^{* *}$ & $0.00^{\text {ns }}$ & $0.00^{\text {ns }}$ & $0.00^{\text {ns }}$ \\
HA x M $^{\circledR}$ & 5 & $0.26^{\text {ns }}$ & $3.25^{* *}$ & $5.23^{* *}$ & $0.00^{* *}$ & $0.04^{* *}$ & $0.01^{* *}$ \\
Error & 36 & 0.16 & 0.43 & 0.50 & 0.00 & 0.00 & 0.00 \\
\hline CV $(\%)$ & & 4.29 & 6.18 & 3.60 & 9.64 & 15.14 & 9.34 \\
Mean & & 9.41 & 10.29 & 19.71 & 0.32 & 0.08 & 0.40 \\
\hline
\end{tabular}

** Significant at $1 \%$ probability. ${ }^{\text {ns }}$ Not significant.

The means of PL and TL were not adjusted by the regression analysis, despite being significant in the ANOVA test (Table 3).

Table 4. Shoot length of cotton seedlings (SL) in the absence and presence of humic acid. Chapadão do Sul, 2013.

\begin{tabular}{cc}
\hline Products & SL \\
\hline Without humic acid & $9.12 \mathrm{~b}$ \\
With humic acid & $9.71 \mathrm{a}$ \\
\hline
\end{tabular}

Means followed by different lower case letters in the column differ from each other at $5 \%$ probability by the Tukey's test.

The addition of $A$. brasilense at a dose of up to $109 \mathrm{~mL} \mathrm{~kg}^{-1}$ of seeds reduced ESI values. The application of Masterfix ${ }^{\circledR}$ at a dose of up to $137.50 \mathrm{~mL} \mathrm{~kg}^{-1}$ increased shoot length to $9.61 \mathrm{~cm}$. Both the humic acid and the Masterfix ${ }^{\circledR}$ product were beneficial for the shoot growth of cotton seedlings. However, the Masterfix ${ }^{\circledR}$ product hinders seeds quality when applied from a determined dose (Figure 2). 


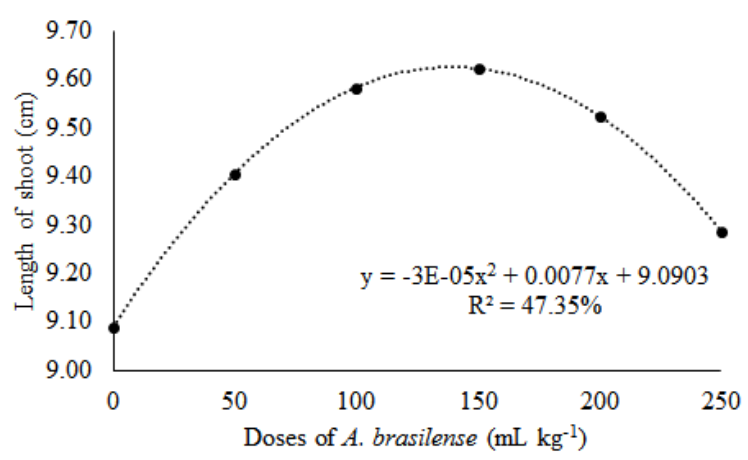

Figure 2. Effect of the doses of A. brasilense on cotton seedlings. Chapadão do Sul, 2013.

Root length increased with the use of humic acid from the application of A. brasilense up to the doses of $200.00 \mathrm{~mL} \mathrm{~kg}^{-1}$ of seeds. Without the application of A. brasilense and at the highest dose, no effect was observed for the use of humic acid on cotton seedlings root length (Table 5). Façanha et al. (2002) suggest the existence of a positive influence of using humic acid on the root development, since this compound increases the production of $\mathrm{H}^{+}$-ATPases of the plasma membrane, and consequently the expansion of the cell wall of the plant tissues, promoting growth and the development of root hairs. The data obtained in this work indicate that the use of humic acid associated with doses of diazotrophic bacteria in cotton seeds favors root development, and this fact may be related to the chemical properties of humic acid. In this sense, Rima et al. (2011) stated that humic acid modified the morphology of the root system and increased the number of physiologically active roots and the root area in corn plants.

The total length of cotton seedlings followed the same behavior as root length, except at the highest dose of $A$. brasilense, which presented no effect (Table 5).

The use of humic acid in the absence of $A$. brasilense and at the lowest dose provided greater shoot dry matter of cotton seedlings. However, the opposite occurred at the two highest doses, reducing shoot dry matter with the use of humic acid. In the absence of A. brasilense, humic acid increased shoot dry matter in $24 \%$, when compared with the control (Table 5). Rosa et al. (2009) evaluated the effect of humic substances extracted from mineral coal on the growth of bean plants, and confirmed an increase in shoot dry matter of up to $30 \%$ when compared with control. However, for root dry matter, inoculation with $A$. brasilense did not provide statistical difference in the absence and presence of humic acid (Table $5)$. 
Table 5. Tukey's test for the unfolding of the interaction of presence and absence of humic acid associated with doses of $A$. brasilense, regarding RL, TL, SDM, RDM, and TDM of cotton seedlings. Chapadão do Sul, 2013.

\begin{tabular}{|c|c|c|c|c|c|c|}
\hline \multirow{2}{*}{ Products } & \multicolumn{6}{|c|}{ Doses of $A$. brasilense $\left(\mathrm{mL} \mathrm{kg}^{-1}\right)$} \\
\hline & 0.00 & 50.00 & 100.00 & 150.00 & 200.00 & 250.00 \\
\hline & \multicolumn{6}{|c|}{ RL } \\
\hline Without humic acid & $9.23 \mathrm{a}$ & $9.35 b$ & $9.45 b$ & $11.01 \mathrm{~b}$ & $9.79 b$ & $9.72 \mathrm{a}$ \\
\hline \multirow[t]{2}{*}{ With humic acid } & $9.91 \mathrm{a}$ & $10.31 \mathrm{a}$ & $10.77 \mathrm{a}$ & $12.17 \mathrm{a}$ & $12.30 \mathrm{a}$ & $9.46 \mathrm{a}$ \\
\hline & \multicolumn{6}{|c|}{$\mathrm{TL}$} \\
\hline Without humic acid & $18.13 b$ & $18.31 \mathrm{~b}$ & $18.53 b$ & $20.82 b$ & $18.99 b$ & $18.62 \mathrm{a}$ \\
\hline \multirow[t]{2}{*}{ With humic acid } & $19.43 \mathrm{a}$ & $19.95 \mathrm{a}$ & $20.35 a$ & $21.86 \mathrm{a}$ & $22.72 \mathrm{a}$ & $18.75 \mathrm{a}$ \\
\hline & \multicolumn{6}{|c|}{ SDM } \\
\hline Without humic acid & $0.29 b$ & $0.30 \mathrm{~b}$ & $0.32 \mathrm{a}$ & $0.32 \mathrm{a}$ & $0.35 \mathrm{a}$ & $0.36 \mathrm{a}$ \\
\hline \multirow[t]{2}{*}{ With humic acid } & $0.36 \mathrm{a}$ & $0.35 \mathrm{a}$ & $0.33 \mathrm{a}$ & $0.32 \mathrm{a}$ & $0.28 b$ & $0.26 b$ \\
\hline & \multicolumn{6}{|c|}{ RDM } \\
\hline Without humic acid & $0.07 \mathrm{a}$ & $0.06 \mathrm{a}$ & $0.08 \mathrm{a}$ & $0.09 \mathrm{a}$ & $0.08 \mathrm{a}$ & $0.09 a$ \\
\hline \multirow[t]{2}{*}{ With humic acid } & $0.08 \mathrm{a}$ & $0.08 \mathrm{a}$ & $0.08 \mathrm{a}$ & $0.08 \mathrm{a}$ & $0.07 \mathrm{a}$ & $0.07 \mathrm{a}$ \\
\hline & \multicolumn{6}{|c|}{ TDM } \\
\hline Without humic acid & $0.36 b$ & $0.36 b$ & $0.41 \mathrm{a}$ & $0.42 \mathrm{a}$ & $0.43 a$ & $0.45 \mathrm{a}$ \\
\hline With humic acid & $0.45 \mathrm{a}$ & $0.44 \mathrm{a}$ & $0.42 \mathrm{a}$ & $0.40 \mathrm{a}$ & $0.35 b$ & $0.34 b$ \\
\hline
\end{tabular}

*Values followed by the same letter in the column did not differ from each other $(\mathrm{p}<0.05)$ by the Tukey's test.

The increase of the doses of $A$. brasilense increased the variables SDM, RDM, and RDM in the absence of humic acid. Conversely, the variables decreased with the use of humic acid (Figure 3). Baldotto et al. (2010) used humic acid and growth regulators in pineapple cultivation, and observed an increase in the efficiency of the inoculation of plant growth promoting bacteria, accelerating the development of inoculated seedlings. However, the same efficiency was not reported in the present work.

In contrast to the results obtained in the present study, where the presence humic acid did not increase SDM, RDM, and TDM when associated with doses of A. brasilense, in a study on the effect of the combined use of plant growth promoting bacteria with humic acid and doses of N, Marques Júnior et 
al. (2008) observed that humic acid acted as a biostimulant in wheat plants, which consequently increased seedlings total dry matter.
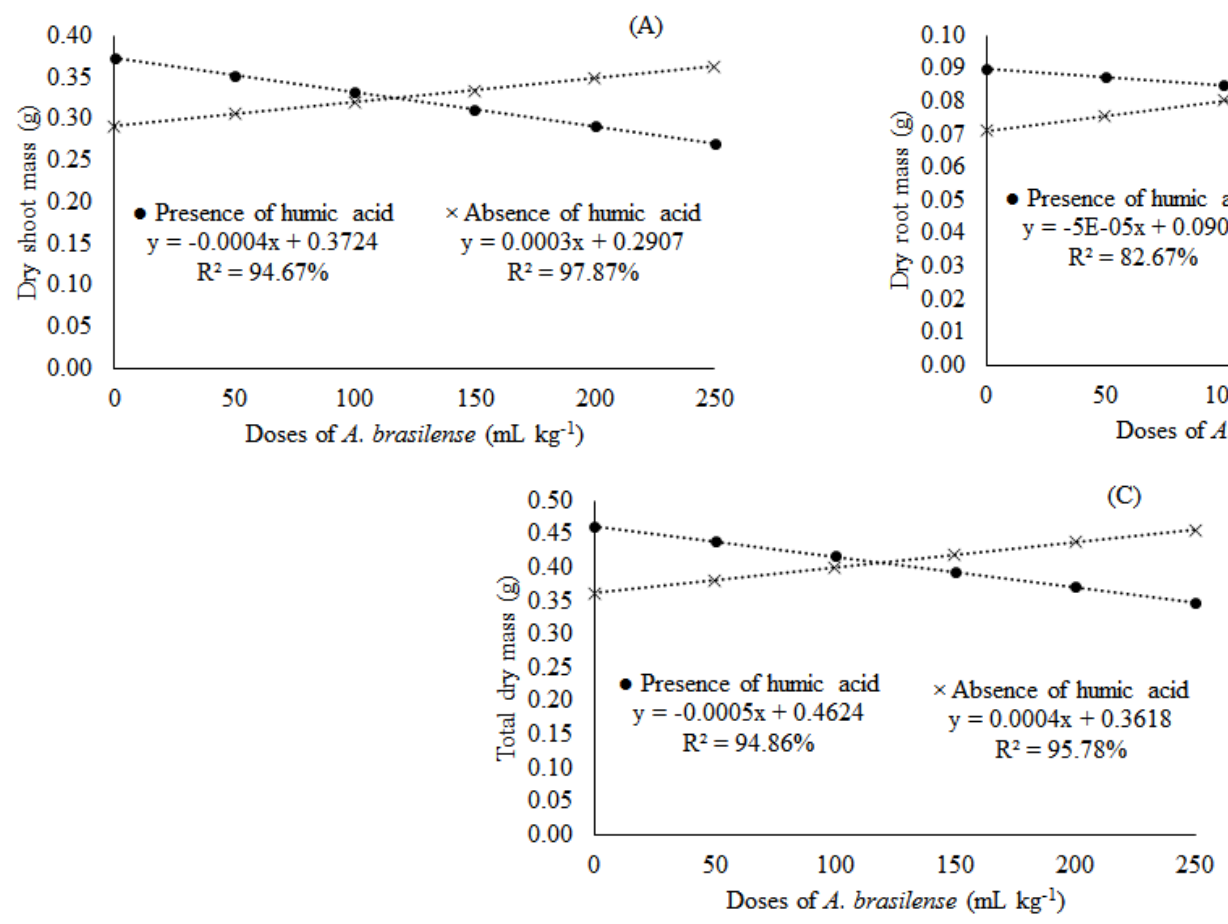

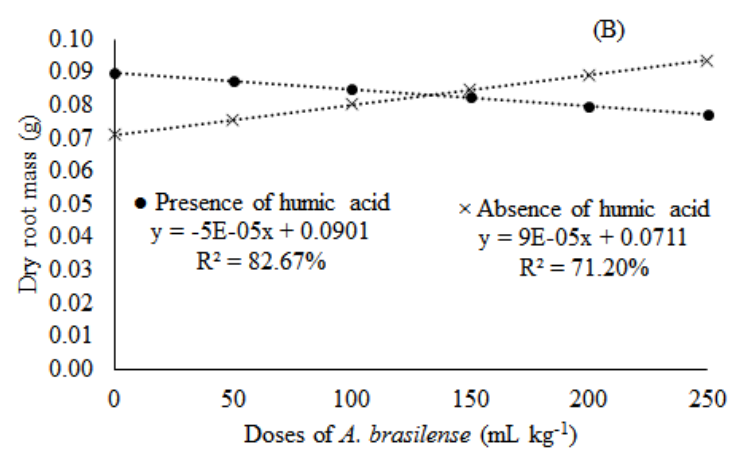

(C)

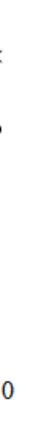

Figure 3. Effect of the dose of A. brasilense on cotton seedlings, where: $(\mathrm{A})=$ shoot dry matter $(\mathrm{g})$; (B) $=$ root dry matter $(\mathrm{g})$; and $(\mathrm{C})=$ seedlings total dry matter $(\mathrm{g})$. Chapadão do Sul, 2013.

The results obtained in this work suggest that cotton seeds can be inoculated with A. brasilense, at the adequate concentration, providing good physiological and germinative performance in the field. In addition, the use of humic acid to increase yield should not be performed empirically, i.e., the source of humic acid, the concentration applied, and the genotype of the plant should also be taken into account (BALDOTTO \& BALDOTTO, 2014). Nevertheless, the application of humic acid and its effects on crops are still uncertain (BALDOTTO et al., 2014), indicating the need for further scientific studies.

\section{CONCLUSIONS}

The isolated use of humic acid or A. brasilense benefits physiological characteristics of cotton seeds.

Higher doses of $A$. brasilense benefit ESI and germination, and hinder shoot length.

Cotton seedlings dry matter increases with the application of humic acid only in the absence of A. brasilense or at the lowest dose of the bacteria. 
Shoot dry matter, root dry matter, and total dry matter increase with the doses of A. brasilense only in the absence of the humic acid.

\section{REFERENCES}

BALDOTTO, L.E.B.; BALDOTTO, M.A.; GONTIJO, J.B.; OLIVEIRA, F.M.; GONÇALVES, J. 2014. Aclimatização de orquídea (Cymbidium sp.) em resposta à aplicação de ácidos húmicos. Ciência Rural, Santa Maria, v.44, n.5, p.830-833.

BALDOTTO, M.A.; BALDOTTO, L.E.B. 2014. Solos e nutrição de plantas: Ácidos húmicos. Revista Ceres, Viçosa, v.61, n.1, p.856-881.

BAlDOTTO, M.A.; CANELA, M.C.; CANELlAS, L.P.; DOBBSS, L.B.; VELLOSO, A.C.X. Redox index of soil carbon stability. 2010. Revista Brasileira de Ciência do Solo, Viçosa, v.34, n.5, p.1543-1551.

BERNARDES, J.M.; REIS, J.M.R.; RODRIGUES, J.F. 2011. Effect of humic substance application on tomato seedlings. Global Science and Technology, Rio Verde, v.4, n.3, p.92-99.

BRASIL. 2009. Ministério da Agricultura: Regras para análise de sementes. Departamento Nacional de Produção Vegetal, Brasília, Brasil, 399p.

CANELLAS, L.P.; TEIXEIRA JUNIOR, L.R.L.; DOBBSS, L.B.; SILVA, C.A.; MÉDICI, L.O.; ZANDONADI, D.B.; FAÇANHA, A.R. 2008. Humic acids crossinteractions with root and organic acids. Annals of Applied Biology, Warwick, v.153, p.157-166.

CASTRO, R. D.; HILHORST, H. W. M. Embebição e reativação do metabolismo. In: FERREIRA, A. G.; BORGHETTI, F. 2004. Germinação do básico ao aplicado. Artmed, Porto Alegre, Brasil, 20p.

CONAB. 2016. Acompanhamento da safra brasileira de grãos: décimo segundo levantamento, Brasília, Brasil, 182p.

CONCEIÇÃO, P.M.; VIEIRA, H.D.; CANELLAS, L.P.; OLIVARES, F.L.; CONCEIÇÃO, P.S. 2009. Efeito dos ácidos húmicos na inoculação de bactérias diazotróficas endofíticas em sementes de milho. Ciência Rural, Santa Maria, v.39, n.6, p.1880-1883.

FAÇANHA, A.R.; FAÇANHA, A.L.O.; OLIVARES, F.L.; GURIDI, F.; SANTOS, G.A.; VELLOSO, A.C.X.; RUMJANEK, V.M.; BRASIL, F.; SCHRIPSEMA, J.; BRAZ-FILHO, R.; OLIVEIRA, M.A.; CANELLAS, L.P. 2002. Bioatividade de ácidos húmicos: efeito sobre o desenvolvimento radicular e sobre a bomba de prótons da membrana plasmática. Pesquisa Agropecuária Brasileira, Brasília, v.37, n.9, p.1301-1310.

FERRARA, G.; BRUNETTI, G. 2010. Effects of the times of application of a soil humic acid on berry quality of table grape (Vitis vinifera L.) Cv Italia. Spanish journal of agricultural research, Madrid, v.8, n.3, p.817-822.

HUNGRIA, M. 2011. Inoculação com Azospirillum brasilense: inovação em rendimento a baixo custo. Embrapa Soja, Londrina, Brasil, 36p.

MAGUIRE, J.D. 1962 Speeds of germination-aid selection and evaluation for seedling emergence and vigor. Crop Science, Londrina, v.2, p.176-177.

MARQUES JÚNIOR, R.B.; CANELLAS, L.P.; SILVA, L.G.; OLIVARES, F.L. 2008. Promoção de enraizamento de microtoletes de cana-de-açúcar pelo uso conjunto de substâncias húmicas e bactérias diazotróficas endofíticas. Revista Brasileira de Ciência do Solo, Viçosa, v.32, n.3, p.1121-1128.

MATYSIAK, K.; KACZMAREK, S.; KRAWCZYK, R. 2011. Influence of seaweed extracts and mixture of humic and fulvic acids on germination and growth of Zea mays L. Acta Scientiarum Polonorum, Poland, v.10, n.1, p.33-45. 
PICCOLO, A. 2001. The supramolecular structure of humic substances. Soil Science, Colorado, v.166, p.810-832.

RAMPIM, L.; KLEIN, J.; TSUTSUMI, C.Y.; MARCHIOTTI, B.G.; GUIMARÃES, V.F. 2014. Desenvolvimento inicial de plântulas de Peltophorum dubium e Leucaena leucocephala inoculadas com bactérias diazotróficas. Floresta, Paraná, v.44, n.4, p.597-606.

ROSA, C. M. DA.; CASTILHOS, R. M. V.; VAHL, L. C.; CASTILHOS, D. D.; PINTO, L. F. S.; OLIVEIRA, E. S.; LEAL, O. A. 2009. Efeito de substâncias húmicas na cinética de absorção de potássio, crescimento de plantas e concentração de nutrientes em Phaseolus vulgaris L. Revista Brasileira Ciência do Solo, Viçosa, v.33, n.4, p.959-967.

RIMA, J. A. H.; MARTIM, S. A.; DOBBSS, L. B.; EVARISTO, J. A. M.; RETAMAL, C. A.; FAÇANHA, A. R.; CANELLAS, L. P. 2011. Adição de ácido cítrico potencializa a ação de ácidos húmicos e altera o perfil proteico da membrana plasmática em raízes de milho.Ciência Rural, Santa Maria, v.41, n.4, p.614-620.

ROCHA, J.C.; ROSA, A.H. 2003. Substâncias húmicas aquáticas: interações com espécies metálicas. UNESP, São Paulo, Brasil, 120p.

RODRIGUES, LUAN F. O. S.; GUIMARÃES, V. F.; SILVA, M. B. D.; JUNIOR, A. S. P.; KLEIN, J.; COSTA, A. C. P. R. D. 2014. Características agronômicas do trigo em função de Azospirillum brasilense, ácidos húmicos e nitrogênio em casa de vegetação. Revista Brasileira de Engenharia Agrícola e Ambiental, Campina Grande, v.18, n.1, p.31-37.

SOUZA, E.; MAGALHÃES, F.; ALVES, C.; CÂNDIDO, A.; SILVA, T.; CUNHA, F. 2014. Inoculação de Azospirillum brasilense na qualidade fisiológica de sementes de milho doce. Nucleus, Ituverava, v.11, n.1, p.131-139. 